Tropical Journal of Pharmaceutical Research, December 2003; 2 (2): 223-228

(C) Pharmacotherapy Group,

Faculty of Pharmacy, University of Benin

Benin City, Nigeria.

All rights reserved.

Available online at http://www.tjpr.freehosting.net

Research Article

\title{
Antibiotics susceptibility patterns of urine bacterial isolates in Zaria, Nigeria
}

\section{Joseph O Ehinmidu}

Department of Pharmaceutics and Pharmaceutical Microbiology, Faculty of Pharmaceutical Sciences, Ahmadu Bello Unversity, Zaria, Nigeria

\begin{abstract}
Purpose: The prevalence of E. coli, Ps. aeruginosa and Staph aureus isolates from urine of selected residents in Zaria was investigated. This was an attempt to elucidate the antibiotic susceptibility profiles of these bacteria commonly implicated in urinary tact infection.

Methods: Urine samples collected from students of Faculty of Pharmaceutical Sciences, Ahmadu Bello University and Kaduna State Polytechnic, Zaria, Nigeria, commercial sex workers, and illiterate men and women in Zaria were cultured and bacterial isolates identified using standard microbiological procedures. The antibacterial susceptibility of the isolated bacteria were investigated.

Results: A total of 206 bacteria were isolated from 150 urine samples collected from the subjects. The prevalence of the Ps aeruginosa, Staph aureus and E. coli isolates from the urine samples is $53.4 \%, 43.3 \%$ and $40.7 \%$, respectively. Commercial sex workers had the highest (30.6\%) prevalence of bacteria in their urine samples while the students had the least. Multiple antibiotics resistance was highest for the bacteria isolates obtained from urine samples of the students and commercial sex workers.

Conclusion: Ps aeruginosa, Staph aureus and E. coli are highly prevalent in urine of the residents of Zaria investigated. The high multiple antibiotics resistance identified makes it necessary for antibiotic susceptibility testing to be conducted prior to antibiotics prescription in in Zaria.
\end{abstract}

Key words: Antibiotics resistance, bacteria, E. coli, Ps. aeuginosa, Staph aureus, urine

E-mail for correspondence: Ehinmidu1953@yahoo.com 


\section{Introduction}

Clinical infection of the urinary tract is said to exist when a significant number of microorganisms, usually greater than $10^{5}$ cells per millilitre of urine, are detected in properly collected mid-stream " clean catch" urine or from a catheter specimen". Infections of the urinary tract are among the most common infectious diseases in humans, possibly because the urinary tract is in direct contact with the exterior ${ }^{1,2}$. Urinary tract infection (UTI) has a propensity to recur. About $25 \%$ of all women with a first UTI has a second re-infection within six months ${ }^{3}$.

The leading causes of acute and uncomplicated UTI in ambulatory patients have been reported to be due to Escherichia coli, Staphylococcus aureus, Proteus spp, Klebsiella spp and Pseudomonas aeruginosa $^{4, .5}$. In Nigeria, E. coli, Proteus spp and Klebsiella spp have been isolated in $90 \%$ of UTI reposted cases ${ }^{6-8}$. The main factor pre-disposing to urinary tract infection has been attributed to poor personal hygiene and culture habit imposition ${ }^{\text {. }}$.

This study was carried out to investigate the prevalence and antibiotics susceptibility patterns of bacteria isolated from urine samples of some residents in Zaria, Nigeria.

\section{Materials and Method}

\section{Media}

Mannitol salt agar, MacConkey agar, Nutrients, Mueller Hinton agar were all Oxoid products (Oxoid, Bassingtoke, United Kingdom).

\section{Urine Samples}

The urine samples from male and female students (15 each) from Kaduna State Polytechnic Zaria, Faculty of Education and Faculty of Pharmaceutical Sciences (Ahmadu Bello University Zaria), illiterate men and women (15 each) from Samaru Village, Zaria, commercial sex workers and men (mostly drivers) that patronized them (15 each) were used for this study. These subjects had a mean age of $30 \mathrm{yr}$ (range, 19 $-45 \mathrm{yr}$ ). A total of 150 urine samples were used for this study. These urine samples were the first 'clean catch' collected with sterile clean bottles. Within $2 \mathrm{hr}$ of collection, each urine sample was immediately inoculated (in triplicates) into MacConkey agar plates, mannitol salt agar plates and cetrimides agar plates on arrival at the laboratory. These were incubated aerobically at $37{ }^{\circ} \mathrm{C}$ for $18 \mathrm{hr}^{10-12}$. The characteristic bacteria isolates observed on the selective media were aseptically isolated and subjected to microscopical and appropriate biochemical tests for proper identification ${ }^{10}$.

\section{Antibiotic susceptibility}

Antibiotic susceptibility test of the isolated test organisms, namely Ps aeruginosa (80), Staph aureus (65) and E. coli (61) against commonly prescribed antibiotics was determined using standard microbiological protocol $^{10,13}$. The standard antibiotics discs used were those of gentamicin (GM, $10 \mu \mathrm{g}$, E. Merck, 6100, Darmstadt, Germany), amoxycillin (Amo $30 \mu \mathrm{g}$, Smithkline Beecham Pharm GMBH 8000, Munchen 40, Germany), spectinomycin (SPT $100 \mu \mathrm{g}$, Unipath Limited, Basingstoke, Hampshire, England), ampicillin (A $10 \mu \mathrm{g}$ ), amikacin (AN $30 \mu \mathrm{g}$ ), erythromycin ( E $15 \mu \mathrm{g})$, penicillin ( $P$ $10 \mu \mathrm{g}$ ), streptomycin (S $10 \mu \mathrm{g}$ ), tetracycline $(\mathrm{TE} 30 \mu \mathrm{g}$ ) and ciprofloxacin (ip $5 \mu \mathrm{g}$ ) all from Becton Dickinson GMBH Post fach 101629 D-6900, Heidelberg, Germany.

Standardized overnight culture of each isolate $\left(10^{6}\right.$ cells $\left./ \mathrm{ml}\right)$ was used to seed melted Mueller Hinton agar (MHA) at $45{ }^{\circ} \mathrm{C}$ and poured into sterilized plates (in triplicates) aseptically. These were allowed to solidify. The standard antibiotic sensitivity dics were then aseptically placed at reasonable equidistance, on the seeded MHA (in triplicates), and allowed to stand for 
$1 \mathrm{hr}$. The plates were then incubated at 37 ${ }^{\circ} \mathrm{C}$ for $18 \mathrm{hr}$ aerobically. The diameter of the zone of inhibition produced by each antibiotic disc was measured using engineer calipers and the result interpreted as earlier described as susceptible (s) or resistance ( $r$ ) to the antibiotic agent used, depending on the length of zone of inhibition produced compared to reported standard length ${ }^{14}$.

Multiple antibiotic resistance index (MAR) (number of antibiotics to which test isolate displayed resistance divided by total number of antibiotic to which the test organism has been evaluated for sensitivity) for each test isolate was calculated as recommended by Krumperman $^{15}$.

\section{Results}

A total of 206 bacteria strains were isolated from the 150 urine samples of men and women screened for bacteria commonly reported in urinary tract infection in this study. The details of these isolates comprising Ps. aeruginosa (80), Staph aureus (65) and E. coli (61) are given in Table 1. Urine samples obtained from the female commercial sex workers and men that patronized them had the highest number of bacteria isolates (30.6\%) while the lowest isolates were recorded from urine samples of students from Ahmadu Bello University, Zaria (14.1\%).

The results of antibiotic susceptibility test of the bacterial isolates indicated that high proportion of the test organisms were sensitive to ciprofloxacin and gentamicin (Table 2). Calculated multiple antibiotic resistance index (Table 3 ) suggests that almost all the test organisms exhibited multiple antibiotic resistance in the following order: Staph aureus $>$ Ps. aeruginosa $>E$. coli.

Result of bacterial isolation from urine samples from the samples investigated indicated that the order of prevalence of these bacteria is Ps. aeruginosa (53.3\%) > Staph aureus $(43.3 \%)>$ E. coli $(40.7 \%)$. The bacterial isolates were most prevalent in the urine samples of commercial sex workers $(30.58 \%)$. This was followed by villagers in Samaru (20.80\%), students from Kaduna State Polytechnic (18.45\%), student from Faculty of Education, Ahmadu Bello University (16.02\%), and lastly by students from Faculty of Pharmaceutical sciences, Ahmadu Bello University (14.08\%).

\section{Discussion}

Some of the isolated bacteria from the urine samples of women in this study have serious

Table 1: Bacteria isolation from urine samples of residents in Zaria, Nigeria

\begin{tabular}{lcccc}
\hline Residents of: & Ps aeruginosa & Staph aureus & E. coli & Total (\%) \\
\hline $\begin{array}{l}\text { Kaduna State Polytechnic } \\
\text { Zaria Nigeria }\end{array}$ & 12 & 5 & 12 & $38(18.5)$ \\
$\begin{array}{l}\text { Faculty of Education, ABU } \\
\begin{array}{l}\text { Faculty of Pharmaceutical } \\
\text { Sciences, ABU }\end{array}\end{array}$ & 18 & 12 & 3 & $33(16.0)$ \\
$\begin{array}{l}\text { Commercial female sex } \\
\text { workers and their male } \\
\text { clients }\end{array}$ & 22 & 11 & 10 & $29(14.1)$ \\
$\begin{array}{l}\text { Uneducated villagers in } \\
\text { Samaru }\end{array}$ & 11 & 20 & 21 & $63(30.6)$ \\
$\quad$ Total & 80 & 17 & 15 & $43(20.8)$ \\
\hline
\end{tabular}

$A B U=$ Ahmadu Bello University 
Table 2: Antibiotic sensitivity profiles of isolated bacteria from 150 urine samples in Zaria, Nigeria

\begin{tabular}{lccc}
\hline \multirow{2}{*}{ Antibiotics } & \multicolumn{3}{c}{ Bacterial isolates sensitive to antibiotics $(\%)$} \\
\cline { 2 - 4 } & $\begin{array}{c}\text { E. coli } \\
(\mathrm{n}=61)\end{array}$ & $\begin{array}{c}\text { Staph aureus } \\
(\mathrm{n}=65)\end{array}$ & $\begin{array}{c}\text { Ps aeruginosa } \\
(\mathrm{N}=80)\end{array}$ \\
\hline Ciprofloxacin $(5 \mu \mathrm{g})$ & 93.75 & 97.06 & 95.35 \\
Gentamicin $(10 \mu \mathrm{g})$ & 78.69 & $91.18 \%$ & 86.05 \\
Erythromycin $(15 \mu \mathrm{g})$ & 3.12 & 30.23 & 8.82 \\
Amoxycillin $(30 \mu \mathrm{g})$ & 6.25 & 6.98 & 5.88 \\
Ampicillin $(10 \mu \mathrm{g})$ & 50.00 & 17.65 & 60.46 \\
Amikacin $(30 \mu \mathrm{g})$ & 3.12 & 5.88 & 6.98 \\
Penicillin $(10 \mu \mathrm{g})$ & 0.00 & 0.00 & 0.00 \\
Streptomycin $(10 \mu \mathrm{g})$ & 16.67 & 20.59 & 58.86 \\
Tetracycline $(30 \mu \mathrm{g})$ & 31.25 & 29.41 & 32.56 \\
Spectinomycin $(100 \mu \mathrm{g})$ & 9.37 & 26.47 & 23.26 \\
\hline
\end{tabular}

health implication in secondary infertility ${ }^{16 .}$ This type of bacteria isolated from the residents is a probable reflection of poor impact of health education on the residents of Zaria whose urine samples were investigated.

Ciprofloxacin is relatively expensive when compared to most antibiotics frequently used in Zaria including the penicillins and tetracylcine. Though relatively cheap, gentamicin is only available for intravenous administration. The observed high level of the isolated organisms' susceptibility to ciprofloxacin might not be unconnected with the high cost of ciprofloxacin. This high cost has probably restricted its procurement and misuse by the residents investigated,

Table 3: Multiple Antibiotic Resistance (MAR) Indices of bacteria in Zaria, Nigeria

\begin{tabular}{cccc}
\hline \multirow{2}{*}{ MAR Index } & \multicolumn{3}{c}{ Frequency of MAR index } \\
\cline { 2 - 4 } & E. coli $(\mathrm{n}=61)$ & $\begin{array}{c}\text { Ps aeruginosa } \\
(\mathrm{n}=80)\end{array}$ & $\begin{array}{c}\text { Staph aureus } \\
(\mathrm{n}=65)\end{array}$ \\
\hline 0 & $1(1.6)$ & 0 & 0 \\
0.1 & $4(6.6)$ & $2(2.5)$ & $1(1.5)$ \\
0.2 & $24(39.4)$ & $16(20.2)$ & $24(37.0)$ \\
0.3 & $14(23.0)$ & $22(27.7)$ & $14(21.6)$ \\
0.4 & $10(16.4)$ & $16(20.2)$ & $16(24.6)$ \\
0.5 & $6(9.8)$ & $14(17.6)$ & $8(12.3)$ \\
0.6 & 0 & $8(10.1)$ & 0 \\
0.7 & $1(1.6)$ & $2(2.5)$ & $2(3.1)$ \\
0.8 & $1(1.6)$ & 0 & 0 \\
0.9 & 0 & 0 & 0 \\
1.0 & 0 & 0 & 0 \\
\hline
\end{tabular}


thereby reducing emergence of resistant bacterial strains. Similarly, the route of administration of gentamicin may have reduced its misuse hence the reduction in the emergence of resistant bacterial strains.

The isolated bacteria were resistant to ampicillin, amoxycillin, penicillin, tetracycline, streptomycin, erythromycin, amikacin and spectinomycin. This observed resistance to these drugs is a probable indication of earlier exposure of the isolates to these drugs, which may have enhanced resistant development ${ }^{15}$.

Multiple antibiotics resistance (MAR) index is a tool that reveals the spread of bacteria resistance in a given population ${ }^{15}$. An MAR index greater than 0.2 .0 implies that the strains of such bacteria originate from an environment where several antibiotics are used. The MAR indices obtained in this study (Table 3 ) is a possible indication that a very large proportion of the bacteria isolates have been exposed to several antibiotics.

It is interesting to note that bacteria isolates from students of Faculty of Pharmaceutical Sciences, Ahmadu Bello University and commercial sex workers had the highest prevalence of antibiotic resistance strain (63.36-100\%) when compared to the isolates from the urine samples of others investigated. This could be due to frequent usage of antibiotics by the students and commercial sex workers.

\section{Conclusion}

Ps aeruginosa, Staph aureus and E. coli are highly prevalent in the urine of the residents of Zaria investigated. The high MAR indices from urine samples isolates in this study appears to suggest a need for continuous monitoring of bacteria antibiotic susceptibility before antibiotic prescription in order to ensure adequate treatment of urinary tract Infection and reduction in the spread of bacteria resistant strain.

\section{References}

1. Williams DN. Urinary Tract Infection: Emerging insights into appropriate Management. Postgrad Med. 1996; 99(4): 189-99.

2. McCaig DJ, Stewart D, Hervey Y, Downie CT, Scott CJ. An assessment of antibiotic therapy of urinary tract infection in elderly, hospitalized patients. Health -Bult Edinb. 1995; 53(6): 35964.

3. Johnson JR, Tiu FS, Stamm WE. Direct antimicrobial susceptibility testing for acute urinary tract infections in women. J Clin Microbiol. 1995; 33(9): 2316-23.

4. Foxman B. urinary tract infection: Incidence and risk factors._Am J Pub Health. 1990; 80, 331-3.

5. Eva $T$, Bendt $M$, Jens $K$. Studies on betalactamases from Escherchia coli Isolated from urinary tract infection. AMPIS. 1990; 98: 34552.

6. Olanipekun KA, Montefiore D. Bacterial infections, sensitivity patterns and chemotherapy among hospital patients in the tropics. Scand $\mathrm{J}$ Infect Dis. 1978; 10: 295-302.

7. Obaseiki-Ebor EE. Trimethoprim Sulphamethiazole resistance in Escherichia coli and Klebsiella spp of urinary isolates. Afri J Med Sci. 1988; 17: $175-9$

8. Sever JL, Ellenberg JH, Edmonds D. Urinary Tract Infection During Pregnancy: Maternal and Paediatric Finding. In: Kass EH, Brumfitt W (eds). Infections of Urinary Tract. Chicago, USA: Chicago Press, 1985 pp 19-21.

9. Johnson JR. Urinary tract infection in women; Diagnosis and treatment. An Int Med. 1989; 111: $109-17$

10. Wolf PL. Practical Clinical Microbiology and Mycology: Techniques and Interpretation New York, USA: John Willey and Sons Inc., 1975 pp 186-8.

11. Odewumi AA. Companion to Practical Microbiology. A Practerical Manual. Zaria, Nigeria: Ahmadu Bello University, 1981.

12. Eweing WH. Edwards and Wing's Identification of Enterobacteriaceae. $4^{\text {th }}$ ed. New York, USA Elsevier Science Publishing Co. Inc., 1986 pp 27-45.

13. Baver AW, Kirby WMM, Sherris JC, Turck M. Antibiotics susceptibility testing by a standardized singles disc method. Am J Clin Pathol. 1966; 145: 493-6.

14. NCCLS. Performance Standards for Antimicrobial Disc Susceptibility Test Approved Standard, M2-A5. Villanova Pan, USA: National 
Committee for Clinical Laboratory Standards, 1993.

15. Krumpermann PH. Multiple Antibiotics Resistance Indexing of $E$. coli to Identify High Risks Sources of Faecal Contamination of Foods. App Environ Microbiol. 1983; 46:165-170.
16. Okonofua FE, Ako-nai KA, Dighitoghi MD. Lower genital tract infection in infertile Nigeria women compared with controls. Gentour Med Jun. 1995; 71(3): 163-8. 